\title{
Wong Ndhuwur, Wong Ngisor: Local Community and Post-disaster Tourism in Kinahrejo
}

\author{
Jordyna Austine Xaviera Susanto'; Wiwik Sushartami ${ }^{2}$ \\ ${ }^{1}$ Independent Researcher, Yogyakarta, Indonesia; \\ ${ }^{2}$ Tourism Studies Program, Universitas Gadjah Mada, Yogyakarta, Indonesia \\ Corresponding Author: sushartami@ugm.ac.id
}

\begin{abstract}
This research has two objectives. First, it aims to determine the perspective of the local community towards the commodification of disaster tourism in Kinahrejo, one year following the 2010 eruption of Mount Merapi. Second, it aims to identify the implication of the local community's involvement in the new tourism activities. Referring to the indicators of residents' perceptions of involvement in post-disaster tourism development (Wright, 2014), semistructured interviews of seven informants were conducted and several more casual conversations were held with a larger group. Two types of responses from the local community were indicated based on the respondents' varying involvement in tourism activities. On one hand, members of the local community who benefit from employment in tourism activities have positive perspectives towards the commodification of disaster tourism in Kinahrejo. On the other hand, those who do not participate in tourism activities regard it negatively as it is not beneficial to them. Another important finding shows that the variation in involvement in the new tourism activities has caused a split in the community into two groups, namely wong ndhuwur and wong ngisor.
\end{abstract}

Keywords: commodification; Kinahrejo; local community; post-disaster tourism; wong ndhuwur, wong ngisor

\section{INTRODUCTION}

Natural disaster tourism is a form of tourism that is not planned in advance and is different from cultural and sustainable tourism. Natural disaster tourism is developed in places that were not originally intended to become tourism sites (Rucinska, 2016). The occurrence of loss of human life and property in the wake of volcanic eruptions, earthquakes, or other acts of nature can turn impacted areas into tourism sites.

Opportunities for the local people and the affected location can arise during a post-disaster recovery phase. One optimistic argument, for instance, claims that natural disasters might bring positive impact to a country in longterm economic growth (Ahlerup, 2013: 11). In the case of Mount Merapi, the post-disaster recovery phase has created a new opportunity for the local community to develop their tourism sector.
The local community plays an important role as the conductor of tourism activities, not to mention they are also the victims of the disaster. Therefore, their perspective of tourism activities is something that should be taken into account. The local community's involvement in the tourism activities is also discussed in this article as these activities are initially conducted to help them reclaim their lives. This article discusses the perspectives of the local community towards the commodification of disaster as tourist attraction and their involvement in conducting tourism activities in Kinahrejo.

Kinahrejo is one out of four Rukun Tetangga (a combination of several households, the lowest administrative division in Indonesia), located in Pelemsari Sub-village, Umbulharjo Village, Cangkringan District, Sleman Regency, Special Region of Yogyakarta. 
According to the head of Pelemsari sub-village, there are 220 people who reside in this sub-village $(\mathrm{R}$, head of Pelemsari sub-village, 16 Januari 2018). Kinahrejo is also located nearest to the summit of the active volcano, Mount Merapi. In 2006, Mount Merapi erupted and claimed two victims who worked as patrol guards. On 27 October 2010, Mount Merapi erupted again and killed 277 people and caused extensive damage to local residents' properties. The National Disaster Management Agency (Badan Nasional Penanggulangan Bencana, BNPN) classified the eruption as a national disaster since the death toll reached hundreds of people (Jakarta Post, 2010). Kinahrejo is registered as kawasan rawan bencana Merapi III (region III Merapi disaster risk area) by the Ministry of Agrarian and Spatial Planning (Figure 1).

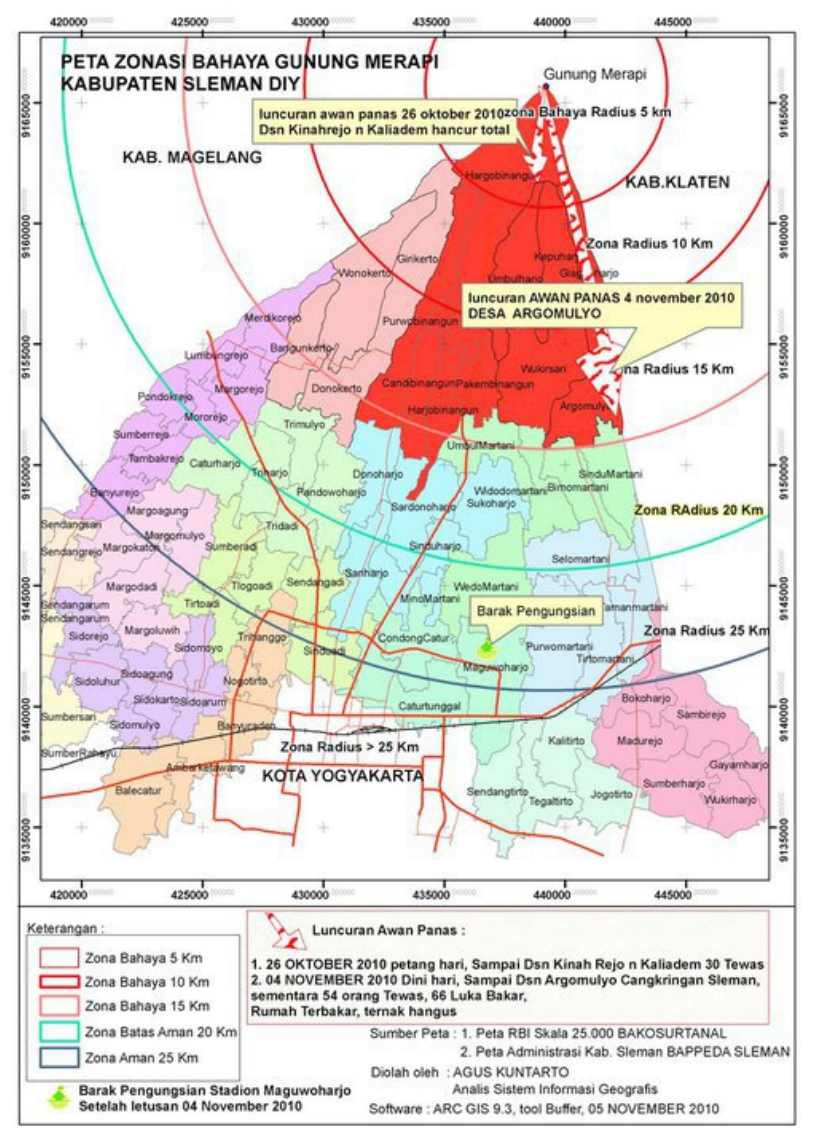

Figure 1. Zonation Map of Merapi Volcano. Source: Kompasiana (2010, 5 November). Merapi, Code dan Pengungsi Yogyakarta. (https://www.kompasiana.com/ eshape/55003f06a33311c56f51053e/merapi-code-dan-pengungsiyogyakarta, retrieved 8 September 2020)

Not long after the disaster occurred, the local community had regained the courage to return to the disaster site. They initiated tourism activities as a way to help the retrieval of the area and commemorate the victims of said tragedy. In 2011, a year after the disaster occurred, Lava Tour was initiated by the local community. The Lava Tour is conducted in Cangkringan, Sleman Regency, Special Region of Yogyakarta. On the Lava Tour, visitors witness the remains of the disaster as well as the documentation of the eruption made by journalists and survivors. One of the highlights of the tour, the house of Mbah (literally "grandparent", commonly used to refer to elderly people) Maridjan is located in Kinahrejo. Mbah Maridjan was one of the victims of the Merapi eruption in 2010. During his lifetime he served as the Guardian (juru kunci) of Merapi.

Visitors can join one of the dozens of Lava Tour operators for a Jeep Tour that includes the driver or rent a trail motorcycle and travel on their own. The operators provide a variety of tour packages that range from two hours with three tourist attractions to the 4.5 hours with about seven attractions. The number of visitors continues to rise annually. In the 2017, it was reported that there were 280,053 visitors, 280 of whom were Foreign Tourists (Dinas Pariwisata Daerah Istimewa Yogyakarta, 2018). This figure indicates a rise of about $20 \%$ compared to 2015, when there were only domestic visitors (Dinas Pariwisata Daerah Istimewa Yogyakarta, 2016). The increase in the number of tourists stimulated an increase in the activities offered on the Lava Tours and the number of Jeeps in operation. There were about 300 jeeps in 2015 , and 720 in 2017 (Nurwandari, 2020: 31).

The trips could cover some of the following attractions: passing by the mass burial of the victims of the 2010 Merapi Eruption; crossing the Opak River to the Kepuharjo village, where tourists can visit Stonehenge Merapi (a replica of the Salisbury Stonehenge), the Museum Sisa Hartaku (Museum of the Remains), the Lost World Castle (a controversial theme park constructed in the region III Merapi disaster risk area) and the Alien Stone (a huge boulder that was carried by the Gendol River during the eruption); and driving after to Kinahrejo Village to visit Kaliadem Bunker (a refuge in the event of a volcanic eruption) and Petilasan (the tomb at the house of) Mbah Maridjan.

Foley and Lennon (1996) stated that disaster tourism is a form of dark tourism. Dark tourism is described as "...the phenomenon which encompasses the presentation and consumption (by visitors) of real and commodified death and disaster sites" (Foley \& Lennon, 1996: 198-211). We can relate this theory to the area that was impacted by the Merapi eruption in 2010 and that has since been turned into a tourism site. 
Ghimire (2016) explains how tourism activities helped the local community's revival in Nepal after an earthquake occurred in 2005. Tourists directly helped the victims because they contributed to improving the victims' post-disaster quality of life. Another example of disaster tourism is the Lower Ninth Ward, New Orleans, Louisiana, which was hit by Hurricane Katrina in 2005. Hurricane Katrina was one of the costliest natural disasters and one of the five deadliest hurricanes in the history of the United States (Blake, Landsea, \& Gibney, 2011: 5). Gotham (2017: 131) states that at least seven travel agents offered Katrina Tours within a span of five years after Hurricane Katrina occurred. The Katrina Tours brought public attention to the devastation of the Lower Ninth Ward, which suffered some of the worst damage. The tours helped gain awareness as well as raised funds to help the victims. The victims whose homes were destructed by the flood often participated in tourism activities as tour leaders in hope that their experiences would contribute to the authenticity of the tour. The tours brought attention to the local community as recovery efforts.

In another case, L'Aquila is a city in Italy that was struck by a massive earthquake in 2009. In the aftermath of the earthquake, L'Aquila became a dark tourism destination. Wright (2014) discussed the perspectives of local residents towards the development of dark tourism in L'Aquila in his research. Wright (2014: 37) found that there has been a lack of attention to the local community who have suffered some form of disaster and who have then become the objects of the dark tourist gaze. In other words, there is a gap of understanding about how local people in post-disaster areas perceive the concept of dark tourism in general. We need to know how the local community perceives their roles as victims who are seen as a tourist attraction. Such knowledge is crucial in the development of dark tourism in a manner that not only meets the needs and expectations of the tourists, but is also beneficial to the local community (Wright, 2014: 37).

The perceptions of the local community should be carefully considered in any tourism development context. This is especially true in areas where not only have death and destruction occurred, but are still present in the living memories of the residents (Wright, 2014: 50).

The local communities living in impacted areas have mixed opinions. In correlation to the topic of Hurricane Katrina disaster, a lifelong resident of the Ninth Ward said that she is fed up with the tourists who came to her neighbourhood to observe post-disaster life as if it were some kind of entertainment. She thought that after all of the suffering they had endured, the victims deserved better treatment (CBS News, 2016 in Gotham, 2017:
132). On the other hand, there were also some positive perspectives regarding the tourism activities. One of the respondents said that the tours would help because then the Ninth Ward would not be forgotten or abandoned (Gotham, 2017: 132).

In the case of L'Aquila, Wright (2014) stressed that the tourism industry and any potential developments are impacted by the mentality of the city.

'L'Aquila's residents have been accustomed to a social reality that is closed, isolated and resilient to outside influences. A closed, suspicious mentality towards 'foreigners' (both national and international) throughout its history is a significant reason why L'Aquila has not recognised the benefits of developing 'dark' tourism or any form of tourism that is focused on the promotion of the earthquake" (Wright, 2014: 388).

This is why this research focuses on the perspectives of the local Kinahrejo community as both survivors as well as tourism activity initiators. This article also addresses the local community's opinions towards the commodification of the post-disaster area in Kinahrejo. By knowing the community's opinions, we can have a better understanding of the reasons they participate or reject tourism activities.

The gap in research of the local perspectives on post-disaster tourism research can be found in a number of studies conducted in Kinahrejo. Surwiyanta (2010) conducted research about the economic, environmental, and sociocultural impacts of the 2006 Merapi eruption on the local people in Kali Adem, one of the tourist sites near Kinahrejo. It was one of the areas most heavily affected by the 2006 eruption. In his thesis, Surwiyanta discussed the impacts of the eruption on the local community and found that the local economy has been growing since then due to its tourism activities. Islami (2014) wrote about the development of Kinahrejo as a tourist destination. This thesis focused on the status of Kinahrejo as a disaster risk area and what could be done by the government to protect the local community while they are conducting tourism activities. Following the 2010 eruption of Mount Merapi and due to the ongoing threat of subsequent eruptions, the government has not permitted the construction of permanent buildings in the impacted area. Meanwhile, Muktaf (2017) conducted a research on the Lava Tours to analyze how disaster tourism is managed. He concluded that as an educational tour, the Lava Tour facilitates communication between the local community and tourists. As disaster tourism provides an opportunity for interaction between witnesses or victims and tourists, it can be part of disaster literacy. 
A place where a disaster has occurred can be commodified as it can create the opportunity to establish disaster tourism in the impacted areas and generate economic activities that can be beneficial to the victims. According to Medina (2003) 'commodification' is the offering of cultural products and practices for money. Therefore, the Lava Tour in Kinahrejo can be perceived as a commodification of disaster as a disaster tourism site since the area and the experiences of the victims are offered as tourist attractions. Disaster tourism can be criticized for showcasing tragedy, but it can change its function to suit the survivors' needs (Nagai, 2012: 10). Disaster tourism can also be seen as the first reconstruction attempt conducted by the victims themselves.

In this research, stakeholders are individuals or a group of people who are associated with tourism development and, therefore, can affect or are affected by tourism activities (Waligo, 2013: 343). As one of the stakeholders, the local community plays a vital role. Members of the local community are the survivors of the disaster who then become the pioneers of tourism activities. The communities can only get the benefits of tourism if they are involved in the attempts to achieve the goal, which is really the case in developing countries as the community dwellers hardly know when and how to get involved and participate in their own development (Ekwale, 2014: 20).

\section{RESEARCH METHOD}

This research is a qualitative research using a descriptiveanalytical approach. The interviews were conducted in a casual and informal manner. Unlike from everyday conversations, which usually do not have preset topics of discussion, semi-structured interviews were conducted following a list of prepared topics and questions. Compared to structured interviews, where less opportunity is available for interviewees to introduce new topics or ask questions, "conversational interviews", using a guided list of questions, give more possibilities for the informants to talk in new yet relevant directions and "respond in an open and authentic way to questions that interviewers might pose to them" (Given, 2008: 128). A set of indicators was also prepared not only to build the question list but also to provide a more systematic and organized method of data analysis. This way, the researcher can easily locate the information on the context of the data (Elliott \& Timulak, 2005: 152).

The indicators of the research were made based on the key research topics used by Wright (2014) in his research about the perspective of local residents towards the development of dark tourism in L'Aquila. Wright (2014: 152) believed that the residents who were also the respondents of the research would be more willing to discuss certain detailed topics on a one-toone in-depth interview and, therefore, allowed a range of detailed information about dark tourism in a post-disaster destination. The key research topics used here focused on the (1) residents' characteristics, (2) residents' attitudes toward tourists and post-disaster tourism, (3) community involvement in post-disaster tourism development, and (4) disasters as opportunities.

In this research, residents' characteristics and attitudes towards post-disaster tourism were the key research topics that helped us to understand the local community's perceptions towards commodification of disaster as a tourism attraction in Kinahrejo. The understanding of the community's involvement in postdisaster tourism development and perception of disaster as an opportunity is intended to answer questions about the local community's participation in tourism activities conducted in Kinahrejo. Using these key research topics, researchers came up with a set of questions adapted to the research objectives, that is, to obtain information about the local community's perspectives towards the commodification of a disaster tourism site as well as their involvement in the tourism activities in Kinahrejo.

Seven informants were interviewed to obtain the data needed for this research. The informants consisted of two local government officers, a member of a youth organisation, a jeep driver, a motor taxi driver, a food stall keeper, and a member of the local community. These informants represent those stakeholders involved in the tourism activities. The informants were identified through snowball sampling. Apart from these seven informants, other members of the local community in the area of Kinahrejo were also involved in more casual conversations to gain more information related to the research.

The local community's behaviour while conducting tourism activities was also observed in order to get a clear picture on how they treat visitors. This could provide additional input regarding their perspectives towards tourism activities. Observation was also conducted during the interviews with members of the local community who have different roles in tourism by observing their responses to the questions. Observing the way they referred to other members of the local community also helped provided insight regarding their relationships with one another as members of the same community. The data for this research was collected in January - March 2018. 


\section{RESULTS AND DISCUSSION Residents' Characteristics}

Certain characteristics can be noted in defining the local people's attitudes before a disaster occurs and how people adjust to life after traumatic events (Wright, 2014: 74). Therefore, to get a better understanding of the local community's characteristics, we need to know their reactions to the disaster the moment it occurred.

On 25 October 2010, after the authorities had issued the highest-level warning possible, all of the local government officers gathered in Umbulharjo Village Meeting Hall to discuss and execute the evacuation plan. The priority was to evacuate the vulnerable groups, such as children, elders, and pregnant women. However, as the local people had become very accustomed to living side by side next to the volcano that erupts periodically, "they tended to take the warning from official authorities very lightly" (M, Service Division of Umbulhardjo Village, 1 March 2018). Nevertheless, some of the local people took the warning seriously; following the instructions given by the evacuation team they immediately went to the assembly point with their families (W, food stall keeper in Petilasan Mbah Maridjan area, 7 March 2018).

However, the evacuation process was not easy. The local people, especially the elders, were not very cooperative during the evacuation. They argued that volcanic materials did not reach their homes during the previous eruptions, therefore evacuation was not necessary. They were also afraid to leave all of their belongings behind, especially their cattle. One member of the evacuation team said that "the moment became chaotic" when they had to pull the local people out of their houses and a loud noise came from the volcano (M, 1 March 2018).

The first eruption happened during maghrib (the evening prayer for Muslims). After that, the evacuation team continued and accelerated the evacuation process with the help of pick-up trucks to transport as many people as possible. Most of the local people had left their homes and were headed to the refuge. However, those who refused to be evacuated were left behind in their homes (M, 1 March 2018).

Most of the local people who were interviewed were able to pinpoint the exact date and time when the disaster happened as if it occurred not so long ago. This disaster occurred over several days starting from 26 October 2010, when the first explosion occurred, to 4 November 2010. It was really something out of the ordinary that "traumatized" the local people and made it an unforgettable experience for them $(\mathrm{L}$, member of a local community, 7 March 2018).

Mbah Maridjan, the gatekeeper of Mount Merapi, was still in his house when the first explosion happened. He refused to leave because he felt that he needed to do his job to take care of the village and remain in his role as a guardian of the volcano. He, along with hundreds of other people, died during the second explosion on 26 October 2010, approximately at 8 p.m. At that point, the refugees were safe in the Umbulharjo Village Meeting Hall. They stayed there for a few days until they were finally moved to Maguwoharjo Stadium to have better care and logistics. The refugees stayed in Maguwoharjo Stadium for approximately a month until they were moved to a temporary establishment where they stayed until the construction of a new permanent residence, Hunian Tetap (huntap) Karangkendal, where the Kinahrejo community was relocated, was completed (R, 7 March 2018).

The eruption had destroyed practically everything in Kinahrejo. After the eruption, all of the inhabitants of Kinahrejo were moved to the huntap. It is located in a safe area approximately $5 \mathrm{~km}$ south of Kinahrejo. As a result of the eruption, a lot of the cattle owned by the local community died because there was not enough time to save them. The fields that had been planted with crops and grass for the cattle were also covered by the volcanic ash and boulders. The field could not be planted for some time after the eruption occurred. This loss of cattle and productive land resulted in the shortage of employment for the local community. As such, they could not immediately recover economically (R, 7 March 2018).

As visitors curious to witness the devastation starting to come to Kinahrejo, some members of the local community began to use the opportunity to make a living. They offered to accompany the visitors as they walked around to see the condition of Kinahrejo. In the beginning, they did not ask for money. However, some visitors still gave them tokens of appreciation nonetheless. Initially, the local people did not intentionally accompany visitors for money. However, the concept of delivering a service to the visitors and receiving payment in return was intriguing, and they undertook to develop it further into something that could increase their incomes. Currently, guiding visitors has become "a source of living for some of the members of the local community of Kinahrejo":

"Mbiyen ki bencana, saiki rejeki, Mbak. Saiki yo ngene iki, narik Jeep, golek duit. Nek raono erupsi mbiyen yo raono ngene iki, Mbak" (T, Jeep driver, 7 March 2018).

(At first it was a disaster, now it's good fortune. 
Now it's like this, get money by driving a jeep. If it weren't for the eruption, it wouldn't be like this.)

What was once just a farming community has now become one of the most well-known tourism sites in Yogyakarta. Kinahrejo is packed with tourists every single day. It took quite some time for the local community to adapt to this condition. Despite the fact that they do not necessarily enjoy living in this circumstance, they have learned to live side by side with the tourists.

For some people, it has become an honour that their village is now such an icon. They are proud to tell people that they come from Kinahrejo because it is now a popular tourism destination and it is located near to one of the most active volcanoes in the world. However, others said that they would prefer Kinahrejo as it used to be, that is, a calm place to live in. It is now increasingly crowded to the point of sometimes disturbing the local residents, especially during holidays.

During peak periods, there are many Jeeps and busses passing through the village, causing inconveniences to the residents who stay in their houses due to the loud noises. When they want to go outside their houses, traffic is inevitable.

The experience of losing their houses and having to stay in the refuge for over 40 days certainly changed the attitudes of the Kinahrejo residents towards the disaster. After the 2010 eruption occurred, the local government gained the people's trust. People realized that the warnings were issued for their own safety. If an eruption ever occurs again, the Kinahrejo residents will most likely follow the evacuation instructions because they have experienced something "so traumatic, that they do not want to relive it" (I, motor taxi driver, 7 March 2018).

This is one positive impact of the eruption. On the other hand, there has also been an undesirable impact on the local community's attitude. According to some sources, some local values have faded. Prior to the rise of tourism activities in Kinahrejo, most of them would describe the local community of Kinahrejo as "polite, warm, and down-to-earth people" (E, leader of youth organization of Umbulhardjo Village, 7 March 2018)

"Apa ya, mbak, istilahnya, masih suka aruh-aruh gitu lho mbak, ya sama siapa aja. Kalo sekarang kan sudah pada sibuk semua. Apalagi yang di atas," (L, 7 March 2018).

(How do you say it? [Formerly, everyone] would greet anyone. But now, everyone is busy. Especially the ones up there)
Whenever they passed each other, people would always greet each other with a smile and chat. Whenever there was an occasion for a celebration, usually a wedding, they would always visit and help their neighbors with the preparations, such as cooking or setting up the janur kuning (yellow coconut leaf erected at the house of the bride's parents to indicate that there was a wedding party). The practice of helping each other prepare for special occasions, rewang, is quite common in villages, but not so much in cities.

Now, those values have changed. Some of the local people are now too busy with the tourism activities that they no longer have the time to rewang. Their former warmness and politeness have been replaced by the urge to profit as possible from tourists. In extreme cases, some local people treat everyone as if they are tourists, which means that they offer assistance only if they can profit from it. For example, when someone asks for directions now, it is unlikely that they will get a direct answer from the local people, which they would have before tourism activities were established. Instead, local residents more often will offer a service as a tour guide or a motor taxi driver which they can profit from (M, 1 March 2018).

\section{Local Community's Perspectives Towards the Commodification of Disaster into Tourist Attractions in Kinahrejo}

The eruption of 2010 inevitably changed attitudes amongst the local people of Kinahrejo. Before the 2010 eruption occurred, they underestimated the evacuation warnings issued by the government authorities. This happened because previous eruptions were not as dangerous as the one that occurred in 2010. The local community is now well aware of the fact that the authorities are merely trying to protect them by taking steps to evacuate them. Therefore, they will not endanger their lives by staying in the disaster risk area when the authorities have issued a warning.

Shortly after the authorities had announced that Kinahrejo was safe, the local community went back to see their remaining belongings and clean up their homes. However, they still lived in the refuge because their homes were destroyed by the eruption. As soon as the authorities lowered the risk status of Kinahrejo, there were many visitors to the area (W, 7 March 2018).

There were two kinds of responses from the local community. Some of them were annoyed by the presence of the visitors. They felt as if they were objects to be gazed upon just because they were victims of a disaster. They got the impression that the visitors were intrigued with 
the fact that they were victims of a horrendous natural disaster and deemed their helplessness worth observing. However, they could not tell the visitors to leave because some of them brought help for the local people in the form of logistics or offered assistance in cleaning up the remains of the disaster. One source explained that visitors took photos and videos of the area. Journalists used professional cameras. However, many visitors took photos with their mobile phones, which caused her to suspect that they were going to post these photos on their personal social media platforms. She found this to be offensive because it made her and her family feel worse about their status as victims (L, 7 March 2018).

However, some of the other local people did not perceive the presence of the visitors negatively. One of the informants described the behaviour of the visitors as gumunan (Jav., "curious", in a sense that people always want to witness an occurrence that just happened). He thought that the visitors saw the condition of the impacted area and they felt sorry. He continued saying that most of the visitors who came to see the situation in Kinahrejo wanted to help by giving donations in the form of logistics and money. Others came to clean the area of the disaster and plant new plants. After the disaster, many organisations opened accounts to distribute donations to the victims of the eruption. Some of them were reliable, while others took profit from the donations and some even scammed the donors. Some visitors just wanted to see Kinahrejo themselves before they offered to help because they were afraid of being scammed, "hence they came to personally deliver their donation." (M, 1 March 2018)

The Kinahrejo community expressed feelings of both rejection and the desire to welcome visitors. In the beginning, the local community felt like objects being gazed upon by the visitors. However, their perspective changed once they knew that these visits had perks. This was how the tourism activities began in Kinahrejo. Villagers started to offer to show the visitors around in exchange for money, which has now developed into more complex tourism activities. This change in attitude occurred only amongst those who participated in tourism activities.

As for those who do not participate in tourism activities, their feelings remain the same. They still struggle to live side by side with the tourists because they are annoyed by the disturbances caused by the tourism activities that they do not profit from.

Maintaining the coexistence of the local community and the tourists requires efforts from both parties. The local people need to welcome the tourists, while the tourists should show good intension and adapt to the local customs to avoid offending the local people. For instance, they need to be cautious when using the main road because there are many children riding bicycles in the area.

Disasters bring death, destruction, and suffering to a community, but they may introduce new opportunities for growth (Davis, 2005 in Wright 2014: 229). Disasters can and arguably should be seen as opportunities for development, as once they have occurred, they can only move forward. Thus, we need to explore to what extent the local people recognize opportunities (Wright, 2014: 137).

\section{Local Community's Involvement in Tourism Activities in Kinahrejo}

For successful tourism development, it is essential to identify the factors that influence the host community's support (or otherwise) for tourism development. In particular, the extent to which the local community is, or perceives itself to be, involved in tourism development is considered to be a decisive factor in community support for tourism, for example, the role of "community involvement" in tourism development (Wright, 2014: 138).

Prior to the disaster, most of the local community of Kinahrejo worked in the agriculture and livestock farming sectors. After the eruption, many of them decided to change their occupations. Most of the newly employed are related to tourism, namely Jeep drivers, motorcycle taxi drivers, street vendors, gatekeepers, and parking attendants. This is an example of how the eruption of Mount Merapi in 2010 created new employment for the local people. Before the eruption, these jobs did not exist. Unfortunate circumstances forced them to come up with initiatives to earn their livings without depending on their previous jobs. Even after Kinahrejo has recovered, they still choose to actively participate in tourism activities because they claim that they generate more money by working in the tourism sector.

However, some members of the local community who participate in tourism activities prefer to refer to the activities they conduct in Kinahrejo as Lava Tours rather than "disaster tourism". They believe that the branding of "disaster tourism" will cast a negative connotation upon Kinahrejo. Furthermore, they point out that tourists come to Kinahrejo not only to see the impact of the eruption, but also to enjoy the view of Merapi from the outlook spot, along with other tourist attractions, such as the mini bird park where they can take photos with birds. They prefer to refer to it as the Lava Tour instead of "disaster tourism" (M, 1 March 2018). 
Those who do not participate in tourism services have nothing much to say about disaster tourism. They briefly responded that they do not know anything about disaster tourism. It is simply because they do not work in the tourism industry. One of them showed no interest whatsoever to know more about disaster tourism (E, 7 March 2018). They did not express any negative opinions about it. They did not think of it as something unethical that should not be promoted. They were more disturbed by the presence of the visitors than the label of "disaster tourism".

Disaster tourism has been perceived as hikmah dari musibah (a blessing in disguise); something good thing that comes out of an unfortunate event. When the eruption occurred, the local community hit rock bottom because they were left with nothing. They had lost all of their homes, belongings and jobs. Yet, they saw an opportunity to make a living by conducting tourism activities. Rather than being bitter over the disaster that occurred, the local community of Kinahrejo chose to make the best out of it. The label of "disaster tourism" does not relate anything unethical to them. As victims, they have the right to make the best out of their misfortune. However, should they be given the option, they would prefer to introduce the tourism activities in Kinahrejo as Lava Tours, rather than labelling it as "disaster tourism." (M, T, and I, 1 March 2018)

There are also some members of the community who now work mining river sand and stone on the slope of Mount Merapi, which are considered to be illegal activities that damage the environment (Jakarta Post, 2013). They ignore this fact, however, because their basic material needs outweigh their moral values, considering the fact that most of them lost almost all of their belongings in the eruption.

\section{Local community's Perception about Disasters as Opportunities}

How the local community of Kinahrejo perceive disasters as opportunities can be seen from their reponses when asked about the future of tourism in Kinahrejo. Members of the Kinahrejo community plan to develop other tourist sites in Umbulharjo Village that were not impacted by the eruption, while maintaining Kinahrejo as its main focus. The local community members who have not participated in tourism activities will be encouraged to be involved in these new sites. The local government plans to encourage the local community to develop a tourism village together. They will not only focus on the remains of the eruption as the main tourist attraction, but will also allow visitors to explore other endeavors in Umbulharjo Village, such as potential flower and coffee plantations. They need to make use of the opportunity "to introduce other specialties from this region” (M, 1 March 2018).

In the future, the local government also plans to revive the Tourism Awareness Group (Kelompok Sadar Wisata, Pokdarwis) of Umbulharjo to create a tour package that includes the attractions owned by the whole village. This tour package will focus not only on Kinahrejo, but also on the entire village to benefit the local community that has and has not yet been involved. For the local community, the future of Kinahrejo's tourism lies in their hands. The local community has high hopes when it comes to tourism activities since it has become their source of living. In order to maintain the number of tourists visiting Kinahrejo, the local community needs to be creative in developing more attractions.

"Potensi seperti kebun bunga dan kebun kopi kan belum pernah ditekuni kalo di sini, jadi mungkin ini jadi kesempatan untuk kami untuk mengembangkan hal yang baru. Sekarang kami harus lebih kreatif dalam membuat daya tarik wisata supaya banyak wisatawan ke sini tidak cuma lihat bekas erupsi saja" (M, 1 March 2018).

([Other] potential activities, such as flower and coffee plantations have never been explored here, so this is an opportunity for us to develop new things. Now we must be creative in developing tourist attractions to that many tourists will come here not just to look at the remains of the eruption.)

Kinahrejo has earned its label as a disaster tourism site. Mbah Maridjan was the renowned gatekeeper of Mount Merapi is what Kinahrejo. The fact that he died in the eruption multiplied the impact on Kinahrejo's image. Mount Merapi will continue to erupt. The local people are aware of this fact. They even say that in the event of another eruption in the future, they would consider it as a blessing. "Kinahrejo will gain more popularity when it happens" (T, 7 March 2018).

During the interview on the topic of disasters as opportunities, it was found that the members of the Kinahrejo community who are not yet involved in tourism activities are actually interested in participating in the future. They are not sure how they can contribute to tourism activities in Kinahrejo. They are hoping that the local government will accommodate them in exploring the potentials of each area that can be developed into a tourist attraction, such as flower and coffee plantations. 


\section{Notable Finding: A Split in the Local Community due to Their Varying Involvement in Tourism Activities in Kinahrejo}

Points 1-4 above covered the local community's perspectives and participation in post-disaster tourism in Kinahrejo. While collecting data to answer key questions using Wright's (2014) indicators, the researchers found an interesting and significant social division within the community that was a result of varying accessibility to tourism activities in Kinahrejo. Wright (2014: 73) cautioned that some degree of community tension during the recovery process is almost unavoidable in a postdisaster environment. However, conflict and the response to it is of a cultural nature and therefore offers various conceptual images in different contexts.

During the conversations with M, T, I, and W (1 March 2018 and 7 March 2018), they mentioned that the local community is now divided into two groups known as wong ndhuwur and wong ngisor. Wong ndhuwur (Jav., literally "people from above") and wong ngisor (Jav., literally "people from below") are words that are used discreetly within the local community of Umbulharjo Village. Some of the informants used the Indonesian phrases orang atas and orang bawah instead of the Javanese words, wong ndhuwur and wong ngisor, or else codeswitched as they also mixed Javanese and Indonesian during the interview.

Before the eruption of the Merapi Mountain in 2010, the terms wong ndhuwur and wong ngisor were mainly used to refer to the spatial position of the local community: wong ndhuwur were those who lived on Umbulharjo Village's upper hill, and wong ngisor lived downhill. However, after the eruption, the use of these phrases changed in context to refer to the people's involvement in tourism. Wong ndhuwur no longer means only those who reside on the upper hill, but also those who are involved with tourism activities as their primary source of living, even though they did not originally live on the upper hill. Wong ngisor, meanwhile, refers to those who used to live in the downhill region of the village and work as farmers or sand miners. Some people who used to live in Kinahrejo, the upper hill, have now become wong ngisor since they moved to Karangkendal huntap, located in the Umbulharjo downhill area and no longer live on the upper part of the hill.

Wong ndhuwur are considered by the wong ngisor as money-oriented. It is said that the wong ndhuwur produce more revenue by undertaking tourism activities after the disaster. Even after Kinahrejo recovered, the wong ndhuwur continue to be involved in tourism activities because they appear to be more profitable. Not all of the wong ndhuwur originated in Kinahrejo. Indeed, the majority of people who originally came from Kinahrejo still work as farmers. Many of those who work in the tourism sector come from Pangukrejo, a sub-village near Kinahrejo. After the eruption, the government compensated local residents. Some of them used the compensation money to buy a Jeep or something else that would allow them to do tourism activities, such as investing in property that could be converted into parking lots. These people became wong ndhuwur

Wong ndhuwur regard tourism as a positive activity for Kinahrejo as a disaster-impacted area. They have a positive outlook on the commodification of disaster as a tourism attraction because they feel they should make the most of the tragedy that ruined their place of living. They refuse to continue to cry over their losses and instead look for a way to survive as they have done by turning tourism activities. They also claim to raise more revenue from tourism by being jeep drivers, motorcycle taxi drivers, street vendors, gatekeepers, and parking attendants than from their previous occupations in the agricultural and livestock farming sectors. The only thing that somewhat disturbs them is the disaster tourism label applied to the tourism operation carried out at Kinahrejo. The wong ndhuwur are worried that the label of "disaster tourism" in Kinahrejo gives negative connotation to tourism activity. They argue that they will focus the tourism promotion not only on the impacts of the eruption, but also on other potential interests in Umbulharjo Village. Thus, rather than promoting disaster tourism, they choose to promote the tourism operation in Kinahrejo as "Lava Tours".

The wong ndhuwur see the wong ngisor as people who cannot invest in the future. They claim that the wong ngisor spent all of the government's financial assistance to them on lavish items and ended up with nothing. As mentioned in point 2 above, there were two distinct responses from the local community to the tourism activities carried out in Kinahrejo. Some people, most of them were wong ngisor, who felt annoyed at being gazed upon by visitors. They were hesitant to engage in tourism activities because they were not comfortable communicating with strangers. They were, thus, not interested in tourism activities, and retained the same attitude toward tourists, even years after the tragedy had occurred. In addition, wong ngisor thought that the visitors contributed to the disparity of their social lives. They said that there is a gap between those who take part in tourism activities and those who do not.

The wong ngisor who do not engage in any kind 
of tourism operation see it as something unwanted. They consider tourism activities to be something they cannot benefit from because they work in the agricultural and livestock farming sectors. They find the tourists irritating because the tourist-filled jeeps drive past their homes. They also said that the tourists are the reason why wong ndhuwur no longer engage in gotong royong (community self-help, mutual cooperation) and rewang. They have lost their sense of community togetherness and put their economy above everything else. As in concern with the interest to be involved in tourism activities that prevailed among some members of the wong ngisor, the informants therefore found it imperative for the local government to support the development of their potential endeavors and to encourage them so that they can engage in more tourism activities (M, T, I, and W, 1 March 2018 and 7 March 2018).

This disparity, however, remains discreet. The two groups do not confront each other over their complaints. The concept of rukun (social harmony) is still upheld and practised among many in Javanese society.

"Ning kene iki urip yo isih guyub, ora pareng ndelok wong seko duite, mbak. Saiki kan wes bedo nek wong ndhuwur karo wong ngisor, mbak." (E, 7 March 2018)

(But here, life is still compact; you can't look at someone just from the money. Now there's a difference between the wong dhuwur and wong ngisor.)

A state of social harmony exists where all parties are in a state of peace, prefer to cooperate, accept each other, in an atmosphere of calm and agreement. Rukun is an ideal state to be retained in all social relations, in the family, in the neighbourhood, in the village, in any fixed group. The entire community's environment should breathe the spirit of harmony (Mulder 1978 in MagnisSuseno, 1991: 39). However, it is sometimes difficult to attain rukun in everyday life. To achieve social harmony, people must practice tepo sliro, which means paying respect to the views and behaviors of others regardless of their differences with our own opinions and customs (Setiawan, 2020: 12). The researchers assume that despite the fact that the wong ndhuwur and the wong ngisor have different perspectives over the commodification of disaster into tourism activities, they can eventually preserve social harmony or rukun through the practice of tepo sliro. In Javanese culture every attempt must be made to approach a conflict with care and wisdom to prevent further escalation of the conflict. The dispute should also be resolved without demeaning any opposing sides. This kind of "conflict management technique" is based on Javanese attitude in seeking harmony (Lestari, Faturochman \& Walgito, 2013: 32).

\section{CONCLUSION}

This research discusses the local community's perspectives towards the commodification of the disaster into a tourist attraction in Kinahrejo. The local community's involvement in conducting tourism activities is explained since they are the victims of the disaster who also take the role of the initiators of tourism activities.

The eruption in 2010 changed the local community in Kinahrejo in both positive and negative ways. In a positive direction, learning from the 2010 casualties, the local community now realises that the authorities meant to protect them by taking steps to evacuate them. Before the 2010 eruption, they downplayed warnings for evacuation. Now, it is unlikely that they would ignore warning issued in the future. The 2010 eruption has also changed the local people into an undesirable direction. The local community of Kinahrejo was described to be warm and caring. However, these characteristics are less apparent in the preference of involvement in tourism activities in Kinahrejo over assisting neighbours when needed. The community tradition of rewang is now considered to be less important in comparison to engagement in tourism activities that can generate income.

Conducting tourism activities is a way for the Kinahrejo community to survive in the aftermath of the eruption in which they lost everything. Initially, the local community was disturbed because they did not like being gazed upon by visitors. Yet, some people had a change of heart once they knew that they could generate income from tourism. This was how the tourism activities began in Kinahrejo. The 2010 eruption of Mount Merapi created new employment opportunities for the local people. Now, even when Kinarejo has recovered from the impact of the eruption, some members of the local community are still involved in tourism activities because it is deemed more profitable compared to their previous jobs in the agriculture and livestock farming sectors.

All members of local community of Kinahrejo should have equal opportunities to be involved in tourism activities. The wong ngisor's aspirations to be involved in tourism needs to be resolved because they are members of the same community which was impacted by the eruption. Therefore, they have the same right to benefit from tourism activities conducted in Kinahrejo.

As part of the community that suffered the most 
in the eruption, the local community of Kinahrejo needs to be given priority in the recovery process. This means that the members of the Kinahrejo community who are interested in participating in tourism activities must be accommodated. Access for the involvement of the wong ngisor in tourism activities is crucial to mending the relationships between them and the wong ndhuwur in order to avoid further tension. Although the Javanese practice of rukun and tepo sliro is still being upheld, we cannot assure in the long run whether the jealousy and tension between the wong ndhuwur and the wong ngisor can create other issues that may affect not only the development of tourism in Kinahrejo, but also their social life in general.

The researchers are aware that the small number of informants may prevent a more general conclusion from being drawn. For the informants who were interviewed and involved in conversations conducted during field research, the research finding should be considered acceptable. Their voices, though limited in number, should be considered worthy of consideration.

Although they are preliminary, the findings of the research regarding the split in the local community between the wong ndhuwur and the wong ngisor are significant. On the one hand, it reveals uniqueness to Wright's (2014) thesis by demonstrating the research's peculiarity and the finding's cultural distinctiveness. On the other hand, the data and the discussion may become insufficient and provisional as such. The researchers therefore suggest more research regarding on the split between the wong ndhuwur and the wong ngisor to gain a better understanding of the essence of this phenomenon and its implications for tourism growth in Kinahrejo economically (how it affects the financial gap between the two groups), politically (how the response of the local government further affects the loosening or hardening of the split), culturally (how the social divide affects the practice of local wisdom), socially (how the split continues to materialise in social disintegration), and how all of these impact sustainable and equal tourism development in Kinahrejo.

\section{REFERENCES}

Ahlerup, P. (2013). Are Natural Disasters Good for Economic Growth? Working Papers in Economics, 553. Departement of Economics, University of Gothenburg. Retrieved: https://core.ac.uk/download/ pdf/16335993.pdf, 8 September 2020.

Blake, E. S., Landsea, C. W., \& Gibney, E. J. (2011). The Deadliest, Costliest, and Most Intense United States Tropical Cyclones from 1851 to 2010 (And Other
Frequently Requested Hurricane Facts). Asheville: National Hurricane Center.

Dinas Pariwisata Daerah Istimewa Yogyakarta (2016). Statistik Kepariwisataan 2015. (https://visitingjogja. com/7659/statistik-pariwisata-2015/, retrieved 8 September 2020)

Dinas Pariwisata Daerah Istimewa Yogyakarta (2018). Statistik Kepariwisataan 2017. (https://visitingjogja. com/15691/statistik-pariwisata-diy-2017/, retrieved 8 September 2020)

Ekwale, A. E. (2014). An Assessment of Local Community Involvement in Community Based Ecotourism Planning and Development: The Case of Takamanda National Par, South West Region, Cameroon. Cyprus: Eastern Mediterranean University.

Elliott, R., \& Timulak, L. (2005). Descriptive and Interpretive Approaches to Qualitative Research. In J. Miles, \& P. Gilbert, A Handbook of Research Methods for Clinical and Health Psychology (p. 152). Oxford: Oxford University Press.

Foley, M., \& Lennon, J. J. (1996). JFK and Dark Tourism: A Fascination with Assassination. International Journal of Heritage Studies, 2, 198-211.

Ghimire, H. L. (2016). Disaster Management and Post-quake Impact on Tourism in Nepal. Journal of Tourism and Hospitality, 6, 67-94.

Given, L.M. (Ed.). (2008). The Sage Encyclopedia of Qualitative Research Method (Vol. 1 \& 2). Los Angeles: Sage Publications, Inc.

Gotham, K. F. (2017). Touristic disaster: Spectacle and recovery in Post-Katrina New Orleans. Geoforum, $86,127-135$.

Islami, M. E. N., \& Putra, H. S. A. (2014). Pariwisata Pascabencana: Kajian Etnosains Pariwisata di Kampung Kinahrejo, Desa Umbulharjo, Sleman. Doctoral Dissertation. Yogyakarta: Universitas Gadjah Mada.

Kompasiana (2010, 5 November). Merapi, Code dan Pengungsi Yogyakarta. (https://www.kompasiana. com/eshape/55003f06a33311c56f51053e/merapicode-dan-pengungsi-yogyakarta, retrieved 8 September 2020)

Lestari, S., Faturochman, M. G. A., \& Walgito, B. (2013). The Concept of Harmony in Javanese Society. Anima, Indonesian Psychology Journal, 29(1), 24-37.

Magnis-Suseno, F. (1991). Etika Jawa. Sebuah Analisa Falsafi tentang Kebijaksanaan Hidup Jawa. Jakarta: PT. Gramedia.

Medina, L. (2002). Commoditizing Culture Tourism and Maya Identity. Annals of Tourism Research, 30(2), 353-368.

Muktaf, Z. M. (2017). Wisata Bencana: Sebuah Studi Kasus Lava Tour Gunung Merapi. Jurnal Pariwisata, 4(2), 84-93. 
Nagai, N. (2012). Disaster Tourism. The Role of Tourism in Post-Disaster Period of Great East Japan Earthquake. Unpublished master research paper. International Institute of Social Studies.

Nurwandari, S. (2020). Pendapat dan Sikap Wisatawan terhadap Risiko dan Keselamatan Operasional Operator Taman Kaliurang Adventure. Undergraduate Thesis. Yogyakarta: Universitas Gadjah Mada.

Rucinska, D. (2016). Natural disaster tourism as a type of dark tourism. International Journal of Humanities and Social Sciences, 10(5), 1458-1462.

Setiawan, B. (2020, January). Rights to the city, tolerance, and the Javanese concepts of "Rukun" and "Tepo Sliro": a portray from five kampungs in Yogyakarta. In IOP Conference Series: Earth and Environmental Science (Vol. 402, No. 1, pp. 012005). IOP Publishing.

Surwiyanta, A. (2010). Dampak Ekonomi, Lingkungan Dan Sosial Budaya Masyarakat Di Kawasan Kali Adem. Media Wisata.
The Jakarta Post (2010, December 2). Death toll from Indonesia's volcano climbs to 275 . (https://web. archive.org/web/20101202120048/http://www. thejakartapost.com/news/2010/11/18/death-tollfromindonesia039s-volcano-climbs-275.html, retrieved 8 September 2020)

The Jakarta Post (2013, December 19). Sleman stops sand mining activities at Mount Merapi. (https://www. thejakartapost.com/news/2013/12/19/sleman-stopssand-mining-activities-mt-merapi.html, retrieved 8 September 2020).

Waligo, V. M., Clarke, J., \& Hawkins, R. (2013). Implementing sustainable tourism: A multistakeholder involvement management framework. Tourism management, 36, 342-353.

Wright, D. (2014). Residents' perceptions of dark tourism development: The case of L'Aquila, Italy. Doctoral Dissertation. University of Central Lancashire. 